\title{
Dietary Supplements: The New Herbalism
}

Lyle E. Craker and Zoë Gardner

Summary. The passage of the Dietary Supplement Health and Education Act in 1994 made the use of supplements more acceptable in the U.S., increasing demand for botanicals to use in health care and maintenance. These botanicals, primarily medicinal and aromatic plants, currently represent about $\mathbf{2 5 \%}$ of the dietary supplement market in the U.S. Although much of the market for botanicals traditionally has been met through collection of plants in the wild, enhanced cultivation of several species will be essential to bring standardized, quality plant materials into the marketplace.

The use of botanical and mineral supplements for health care dates back to the beginning of human history. With the advent of pharmaceutical remedies in the last century, however, use of many of these dietary supplements fell from favor in the United States and other westernized countries. Only with the passage of the Dietary Supplement Health and Education Act (DSHEA) in 1994 (U.S. Congress, 1994), did these products become legitimized, increasing consumer confidence in the supplements and launching a repopularization of these health aids. The DSHEA legislation permits herbs, vitamins, and other supplements to be marketed and sold as dietary supplements rather than drugs, eliminating the costly and time consuming U.S. Food and Drug Administration drug approval process, yet also strictly regulates labeling of supplements to prevent misleading marketing. Following the passage of DSHEA, sales of dietary supplements markedly increased, most notably between 1997 and 1999, with over 70\% of the U.S. households using supplements by 1999 (Gottieb et al., 1999).

Although the rapid growth in the supplement market has recently slowed, causing a slight decrease in sales during 2000 (Taormina, 2001 ), interest in supplements remains high. In 2000, supplement sales exceeded $\$ 16.8$ billion with three of every five U.S. consumers taking supplements on a regular basis (Dietary Supplement Education Alliance, 2002). Most consumers probably began purchasing dietary supplements to maintain optimum health, slow the aging process, meet nutritional needs, or improve physical performance, but dietary supplements, particularly the botanicals, have become widely used as health remedies (Israelsen, 1998). 
The market for herbal remedies (botanicals) as dietary supplements includes both prescription and overthe-counter sales with applications in the food, healthcare, cosmetic, and veterinary industry. In 2000 , consumer sales of dietary supplements made from botanicals was more than $\$ 4$ billion (Blumenthal, 2001), representing 25\% of the dietary supplement market (Dietary Supplement Education Alliance, 2002). The potential U.S. market for botanicals as dietary supplements has been estimated at $\$ 25.8$ billion (Hoffman, 2001).

\section{Markets}

Herbal remedies have a long, historical association with the human need for health and the quest for youth and beauty. Ancient texts and scriptures linked with centers of early civilizations indicate that medicinal and aromatic plants frequently served as the principal constituents for embellishing the body and curing ailments (Hobbs, 2002). Casual observations today suggest that grocery stores, pharmacies, and convenience stores are devoting considerable more shelf space to herbal medicines than at any time in the recent past. U.S. markets for botanicals as dietary supplements are expected to increase at about $8 \%$ per year (Gruenwald, 2000). Recent reports in Time (Greenfield, 1998; Greenwald, 1998) magazine indicate that in the U.S., the market for herb-spiked drinks has moved from $\$ 20$ million to $\$ 700$ million in 4 years. A report in Whole Foods (Richman and Witowski, 2000) magazine indicated that in U.S. health food stores, $36 \%$ of the foods contained medicinal or aromatic plant materials.

An array of old and newly recognized medicinal and aromatic plants, essential oils, and botanical extracts have gained prominence in natural product markets, fueled by changes in demographics and personal choices about self-care (Table 1). An informal survey of customers at a local health food store (Hadley, Mass.) conducted in Spring 2001, suggested that consumers desire products that improve health, contain natural ingredients, are environmentally sound, preserve social and cultural values, are unadulterated, and satisfy the consumer need to feel good about purchasing the product. Each consumer also mentioned the health aspects associated with natural products and the availability of medicinal and aromatic plants for health maintenance. Sales of many botanicals as dietary supplements are, to a large extent, driven by the news media. Following several popular media feature stories on herbs in 1997, sales of a number of herbal remedies dramatically increased (Table 2). But likewise, a report in the Journal of the American Medical Association (Hypericum Depression Trial Study Group, 2002), indicating that st. john's wort (Hypericum perforatum) had no effect on severe depression, was featured without

Table 1. Demographics of herbal supplement users (data of Molyneaux, 2002).

\begin{tabular}{ll}
\hline Age & About $60 \%$ are $\geq 46$ years old \\
Education & Mostly college educated and many with post graduate degrees \\
Lifestage & Older, $55 \%$ represent single, retired couples, and parents \\
Household & Limited, $60 \%$ live in one or two-person homes \\
Income & Slightly higher than average \\
Health & Self-care seekers, practice prevention \\
Supplement & Regular use of herbal supplements by $16 \%$
\end{tabular}

Table 2. Sales of medicinal herbal products in the U.S., June 1997 to June 1998 (Data of Brevoort, 1998).

\begin{tabular}{lc}
\hline Medicinal herb & Sales increase (\%) \\
\hline St. John's wort (Hypericum perforatum) & 2,801 \\
Green tea (Camellia sinensis) & 1,007 \\
Black cohosh (Cimicifuga racemosa) & 511 \\
Elderberry (Sambucus nigra) & 497 \\
Kava (Piper methysticum) & 473 \\
Soy (Glycine max) & 163 \\
Echinacea (Echinacea spp.) & 151 \\
\hline
\end{tabular}

comment by almost every large and small newspaper in America, leading many customers away from an herb that is generally considered useful for treatment of mild or moderate depression.

In addition to media attention, several other factors, including changing attitudes on healthcare and shifting demographics, are affecting the sales and use of dietary supplements. Societal recognition of the shortcomings of pharmaceutical medicine, a desire for more holistically-based healthcare, and consumer self-care empowerment are responsible for much of the growth of the supplement industry (Dietary Supplement Education Alliance, 2002). Demographically, an aging population is influencing supplement use (Table 3). Each minute from now until 2010, seven Americans will turn 55 years old, and currently about 35 million Americans are age 65 years or older (U.S. Census Bureau, 2001). Sales of soy (Glycine max) and black cohosh [Cimicifuga racemosa (syn. Actaea racemosa)] products have jumped in the past 2 years as more women enter menopause and seek natural supplements to ease the associated symptoms. Sales of flax (Linum usitatissimum) and evening primrose (Oenothera biennis) oils have increased as people have become familiar with the medical benefits of omega- 3 fatty acids and g-linolenic acid in the plant tissues (Simopoulos, 1999).

Many recent scientific studies support the use of dietary supplements in healthcare. For example, in 1999, a new class of pharmaceutical drugs, the cyclooxygenase-2 (COX-2) inhibitors, became available. The COX-2 drugs block an enzyme responsible for the pain and inflammation of arthritis and may prove to be key cancer preventative drugs. Several medical studies on herbs such as ginger (Zingiber officinale), turmeric (Curcuma longa), green tea (Camellia sinensis), and holy basil (Ocimum sanctum), have demonstrated that these herbs also have significant COX-2 inhibitory action and lack the side effects of the pharmaceutical versions (Babal, 2001; Haqqi et al. 1999; Suh et al. 1998).

To be accepted as legitimate pharmaceuticals, however, herbal medicinals must pass expected market standards for identity, quality, and bioactivity. As noted by a recent evaluation of 25 commercial echinacea 
Table 3. U.S. population and potential markets by generation (Data from U.S. Census Bureau, 1996).

\begin{tabular}{lc}
\hline $\begin{array}{l}\text { Market } \\
\text { classification }\end{array}$ & $\begin{array}{c}\text { Size } \\
\text { (millions) }\end{array}$ \\
\hline Swing/WWII (1933-45) & 30.7 \\
Baby Boomers (1946-64) & 76.8 \\
Generation X (1965-78) & 52.4 \\
Baby Boomlet (1979-94) & 77.6 \\
\hline
\end{tabular}

(Echinacea spp.) products in which $44 \%$ failed a test that examined product labeling and plant materials (Natural Products Industry Insider, 2001), not all products are satisfactory. $\mathrm{Al}$ though some dietary supplement companies are attempting to standardize the activity of herbal medicines, such attempts depend on knowing the active plant constituents and having appropriate testing equipment. If products can be standardized at active levels of the active constituent(s), sales of these supplements can be expected to continue to increase (Table 4).

\section{Plant materials}

With market demand for medicinal and aromatic plant products strong and expected to remain strong, work in herb production, protection/conservation, domestication, genetic transformation, and constituent standardization is needed (Craker, 2003). To effectively cultivate medicinal and aromatic plants that have been traditionally collected, information is needed on plant life cycles, breeding behavior, seed biology, and a host of other plant variables. Investigations are needed on plant growth and development, population and habitat viability, post harvest handling, and methods for producing crops with consistent levels of biologically active constituents. Cultivar, nutrition, and pest control trials are needed for cultivated medicinal species.

More needs to be learned about producing medicinal and aromatic plants, utilizing organic farming methods, and the processing of the plant material with practices that preserve bioactive constituents. All of this information is needed for a multitude of medicinal herbs grown in a range of light, temperature, moisture, and soil environments (Craker, 1999).

In medicinal and aromatic plant production, the ground-work has been laid with the development of good agricultural practices (GAPs), good manufacturing practices (GMPs), and good collecting practices (GCPs) (Máthé and Franz, 1999; Harnischfeger, 2000), guidelines for bringing quality medicinal plant materials to the market. The Medicinal and Aromatic Plant Section within the International Society for Horticultural Science vigorously supports the guidelines that ensure that international trade in medicinal plants meets acceptable standards for value (Bernáth et al., 1993). Following the guidelines, each grower and plant collector helps ensure that wholesome medicinal and aromatic plants reach markets.

In addition to developing agricultural techniques, plant conservation issues must be addressed. Much of the demand for medicinal plant materials is currently being met by harvest of wild plants. About $90 \%$ of the medicinal plant materials used by Europeans, for example, are wildcrafted (Lange, 1998). In the U.S., officials at the Great Smoky Mountains National Park estimate that over $\$ 5$ million dollars worth of american ginseng (Panax quinquefolius) has been illegally harvested on park land in the last 9 years (Nickens, 2001). Rangers in national forests of North Carolina have witnessed a decline in ginseng density from 29.8 plants per plot in 1979 , to 5.7 plants per plot in 1999 (U.S. Fish and Wildlife Service, 2001).

Gathering firm evidence on medicinal plant production in the North America is difficult due to a lack of government tracking for most species.

Table 4. Value of U.S. botanical markets (\$ millions) (Data of Brookman, 1999).

\begin{tabular}{lrrr}
\hline Item & $\mathbf{1 9 9 3}$ & $\mathbf{1 9 9 8}$ & $\mathbf{2 0 0 3}$ \\
\hline Plant chemicals & 1185 & 1890 & 2935 \\
Essential oils & 465 & 625 & 820 \\
Botanical extracts & 268 & 560 & 1120 \\
Gums, gels, polymers & 274 & 392 & 500 \\
Other & 178 & 313 & 495 \\
\hline
\end{tabular}

Estimates suggest, however, that 175 native North American species of medicinal plants (cultivated and collected) are offered for sale in the non-prescription medicinal market of the United States (Lyke, 2000). Robbins (1999) has documented that over 140 North American species are sold in foreign countries. This large number of medicinal species with a variety of environmental habitats, physiological processes, active constituents, and markets limits the development of general horticultural recommendations related to cultivation and collection, but highlights opportunities for growers of medicinal plants.

\section{Prospects}

Use of medicinal and aromatic plant materials as dietary supplements is guided by a mixture of myth, tradition, and science, frequently based on biases, misconceptions, and limited research. The lack of standardization of active constituents in medicinal plants has empowered the U.S. press and medical profession to frequently label medicinal plant materials snake oil, a derogatory term that implies the material is worthless as a medicine. To overcome this negative label, the future must bring to market medicinal and aromatic plant products with consistent levels of research-defined, active ingredients.

The education of consumers and healthcare workers in the appropriate supplement and pharmaceutical uses of medicinal and aromatic plants should lead to an honest evaluation of the therapeutic role these plant materials can play in individual health. The growth in product sales during the recent past helps identify a strong consumer interest, necessitating support of continued research in plant production and protection, support of clinical trials in herbal medicine, and development of standards that guarantee supplement wholesomeness and efficacy. A view to the future suggests eventual integration of pharmaceutical and complementary/holistic medicine within medical centers.

\section{Literature cited}

Babal, K. 2001. Shelf stockers for 2001. Nutr. Sci. News, Jan. 2001. 23 July 2001. <http://www.new hope.com / nutritionsciencenews/NSN_backs/ Jan_0l>. 
Bernáth, J., L.E. Craker, and A. Levy. 1993. Recommendations from the First World Congress on Medicinal and Aromatic Plants for Human Welfare. Acta Hort. 330:14.

Blumenthal, M. 2001. Herb sales up 1\% for all channels of trade in 2000 . HerbalGram 53:63.

Brevoort, P. 1998. The booming U.S. botanical market: A new overview. HerbalGram 44:33-47.

Brookman, F. 1999. Are you being served? Soap, Perfumery, and Cosmetics 72(7):3842

Craker, L.E. 1999. Trends in medicinal and aromatic plant production in the United States. Acta Hort. 502:71-75.

Craker, L.E. 2003. Production and demand: A view to the future of MAP. Acta Hort. (in press).

Dietary Supplement Education Alliance. 2002. The market for dietary supplements. 13 May 2002. <http://www.supplementinfo.org/industry/marketplace.htm>.

Gottieb, B., R. Hashizume, and L. Demeritt. 1999. Vitamins, minerals, herbs and supplements: A year in review. N|sight. Fall 1999:5-6.

Greenfield, K.T. 1998. New health drinks or old-style snake-oil elixirs? Time 152:61.

Greenwald, J. 1998. Herbal healing. Time 152:60-63.

Gruenwald, J. 2000. The supplement markets in the U.S. and Europe. Nutraceuticals World 3(6):36-37.

Harnischfeger, G. 2000. Proposed guidelines for commercial collection of medicinal plant material. J. Herbs, Spices Med. Plants 7(1):43-50.

Haqqi, T.M., D.D. Anthony, S. Gupta, N. Ahmad, M.S. Lee, G.K. Kumar, and H. Mukhtar. 1999. Prevention of collageninduced arthritis in mice by a polyphenolic fraction from green tea. Proc. Natl. Acad. Sci. 96:4524-4529.
Hobbs, C. 2002. An outline of the history of herbalism-Anoverviewand literature resource list. 3 June 2002. <http:/ / www.healthy.net/ asp/templates/article.asp? Page Type $=$ Article\&ID=901>

Hoffman, F.A. 2001. Industry and the role of NCCAM in the development of complementary and alternative medicine products for the US market. National Center for Complementary and Alternative Medicine (NCCAM) Industry Colloquium, Wash., D.C. 14 May 2001. 14 July 2001. <http:/ /nccam.nih.gov/news/pastmeetings/ 051401/hoffman/index.htm>.

Hypericum Depression Trial Study Group. 2002. Effect of Hypericum perforatum (st. john's wort) in major depressive disorder: A randomized, controlled trial. J. Amer. Med. Assn. 287:1807-1814.

Israelsen, L.D. 1998. Botanicals and DSHEA: A health professional's guide. Quarterly Rev. Natural Med. (Fall 1998):251-257.

Lange, D. 1998. Europe's medicinal and aromatic plants: Their use, trade, and conservation. A TRAFFIC species in danger report. 24 June 2001. <http://www.traffic.org/plants/ executive-summary.html>.

Lyke, J. 2000. The medicinal plant working group. Endangered Species Bul. 25(1-2):2021

Máthé, Á. and C. Franz. 1999. Good agricultural practice and the quality of phytomedicines. J. Herbs, Spices and Med. Plants 6(3):101113.

Molyneaux, M. 2002. Consumers attitudes predict upward trends for the herbal marketplace. HerbalGram 54:64-65.

Nickens, T.E. 2001. Catching bandits in the Smokies. National Wildlife, Feb./Mar. 2001. 15 June 2001. <http://www.nwf.org/ nationalwildlife/2001/ginseng.html>.

Natural Products Industry Insider. 2001. ConsumerLab.comfails44percentofechinacea products. Natural Products Industry Insider, 7 May 2001. 9 July 2001. <http:// www.naturalproductsinsider.com/hotnews/ 15h7152218.html>.
Richman, A. and J.P. Witkowski. 2000. Herb sales hit record levels. Sixth annual herb products sales survey. Whole Foods 23(11):52-59.

Robbins, C. 1999. Medicine from U.S. wildlands: An assessment of native plant species harvested in the United States for medicinal use and trade and evaluation of the conservation and management implications. The Nature Conservancy, Wash., DC.

Simopoulos, A.P. 1999. Essential fatty acids in health and chronic disease. Amer. J. Clinical Nutr. 70:560S-569S

Suh,N., T.Honda, H.J.Finlay, A. Barchowsky, C.Williams, N.E. Benoit, Q.W.Xie, C.Nathan, G.W. Gribble, and M.B. Sporn. 1998. Novel triterpenoids suppress inducible nitric oxide synthase(iNOS) and inducible cyclooxygenase (COX-2) in mouse macrophages. Cancer Res. 58:717-723.

Taormina, S. 2001. Supplement sales struggle in 2000. Natural Foods Merchandiser, June 2001. 8 July 2001. <http://www.exchange. healthwell.com/nfm-online/nfm_backs / Jun_01/struggle.cfm>.

U.S. Census Bureau. 1996. Population projections of the United States by age, sex, race, and Hispanic origin: 1995 to 2050.5 June 2001. <http://www.census.gov/prod/1/pop/ p $25-1130 />$.

U.S. Census Bureau. 2001. The 65 years and older population: 2000.5 June 2001. <http:/ /www.census.gov/prod/200lpubs/ c2kbr01-10.pdfs.

U.S. Congress. 1994. Dietary Supplement Health and Education Act of 1994, Public Law 103-417. Washington D.C., Government Printing Office. 8July 2001.<http://www.fda. gov/opacom/laws/dshea.html>.

U.S. Fish and Wildlife Service. 2001. Memo from Chief, Division of Management Authority to Chief, Branch of Consultation and Monitoring, Division of Scientific Authority, 2001. 12 June2001. <http://international.fws.gov/ animals/ginfin0l.html>. 